\title{
Threshold valves to create positive end-expiratory pressure (PEEP) in conventional large animal anaesthesia ventilators and circuits
}

\author{
Nina Küls, Christina Braun, Peter Johann Schramel and Yves Moens \\ Anaesthesiology and Perioperative Intensive Care Medicine, University of Veterinary Medicine, Vienna, Austria
}

\begin{abstract}
Summary: The use of positive end-expiratory pressure (PEEP) and alveolar recruitment manoeuvres (ARMs) has become a promising treatment option for perioperative alveolar collapse and subsequent hypoxaemia in equine patients. Unfortunately, only the newest generation of large animal ventilators, not using the bag-in-the-box principle, are able to automatically create sufficiently high PEEP levels for horses. To create a large range of PEEP in the commonly used bag-in-the-box ventilators and breathing circuits, threshold resistor valves can be added. These devices built up an adjustable PEEP by creating a force against the expiratory gas flow, thereby establishing a constant threshold pressure. Examples are the underwater seal, the spring-loaded threshold valve and the magnetic valve. However, there are some important aspects that need to be considered when using these devices. The location of both the threshold resistor and the PEEP measuring device within the circuit will determine, if PEEP can be detected within the entire breathing system. Furthermore, the time it takes to establish a stable PEEP within the system depends on the type of the threshold valve, and may be influenced by several other factors, e.g. the total gas volume in the circle, the type of ventilator used and the individual horse's lungs. In an in vitro study using an artificial lung the onset of PEEP was dependent on the fresh gas flow used - the higher the fresh gas flow, the faster the onset of PEEP. However, in vivo, the onset of PEEP was independent of the fresh gas flow and was, compared to the in vitro study, significantly slower. It is therefore paramount to monitor the pressures within the circuit and carefully observe the time it takes to build up PEEP for each individual horse.
\end{abstract}

Keywords: Equine anaesthesia, ventilation, Positiv End-Expiratory Pressure, Alveolar Recruitment Manoeuvre, ventilator, resistance valve

Citation: Küls N., Braun C., Schramel P. J., Moens Y. (2016) Threshold valves to create positive end-expiratory pressure (PEEP) in conventional large animal anaesthesia ventilators and circuits. Pferdeheilkunde 32, 457-460

Correspondence: Nina Küls, Dept. for Anaesthesiology and Perioperative Intensive Care, Veterinary University of Vienna, Veterinärplatz 1 , 1210 Wien, Austria; E-mail: nina.kuels@vetmeduni.ac.at.

\section{Introduction}

In recent decades ventilation strategies were investigated in equine anaesthesia with the aim to counteract the extensive atelectasis and subsequent impairment of oxygenation commonly observed (Hall et al. 1968, McDonell 1979). A key element is the application of alveolar recruitment manoeuvres (ARMs) during mechanical ventilation, which require transitory high airway pressures followed by positive end-expiratory pressure (PEEP). Documented levels for effective PEEP in the equine setting are higher than commonly used in human medicine and reach up to $30 \mathrm{~cm} \mathrm{H} \mathrm{H}_{2} \mathrm{O}$. Some ARMs use stepwise increase and decrease of PEEP that requires a quick and reliable realization of the different PEEP steps (Levionnois et al.2006, Wettstein et al. 2006, Hopster et al. 2007, Schürmann et al. 2008, Bringewatt et al. 2010, Hopster et al. $2011,2016 a, b)$. Unfortunately few conventional large animal ventilators of the "bag-in-the-box" type are capable of creating PEEP or allow only for low PEEP values up to $10 \mathrm{~cm}$ $\mathrm{H}_{2} \mathrm{O}$. A new generation of motor driven large animal ventilators like the Tafonius large animal ventilator ${ }^{1}$ and the custom made Horsevent large animal ventilator ${ }^{2}$ fulfil modern requirements for PEEP and allow for a maximum PEEP of $50 \mathrm{~cm}$ $\mathrm{H}_{2} \mathrm{O}$ and $30 \mathrm{~cm} \mathrm{H}_{2} \mathrm{O}$, respectively.

Conventional large animal ventilators and circuits can be customized to allow creation of sufficient PEEP by adding PEEP-creating devices to the ventilator or the breathing system. Various types of threshold valves can be used, which rely on different mechanical principles. A threshold valve device exerts a constant, quantifiable and predictable force against a gas pressure thereby establishing a constant pressure limit. Only pressures exceeding a threshold will allow flow through the device and hence, constant PEEP levels are maintained regardless of fresh gas flow (Kacmarek et al. 1982). Few types of threshold valves have been used and documented in equine anaesthesia.

\section{The underwater seal}

One type of threshold valve used in equine anaesthesia is the underwater seal which is a gravity-dependent threshold valve placed in the expiratory limb of the breathing circuit that was first described by Mclntyre in 1969 and subsequently used by others (Hall and Trim 1975, Beadle et al. 1975, Levionnois et al. 2006, Iff et al. 2007). Alternatively, the underwater seal can be connected to the exhaust port of the bag-in-the-box ventilator to create PEEP. With this device a threshold pressure is developed by submerging a tube connected to the expiratory limb of the circle system (or the ventilator exhaust port, respectively) into a water reservoir to a depth equivalent to the amount of PEEP required (Figure 1). Once the pressure in the expiratory limb exceeds the threshold pressure, water is displaced in the submerged portion of the tube, allowing gas to bubble through the water and exit the device through the expiratory limb of the circle system. The underwater seal has been shown to exhibit almost ideal threshold characteristics and the best agreement between selected pressures and those actually achieved (Christensen et al. 1995). The authors made similar observations. Disadvantages encountered with this system are the size and bulkiness of the device, and the 

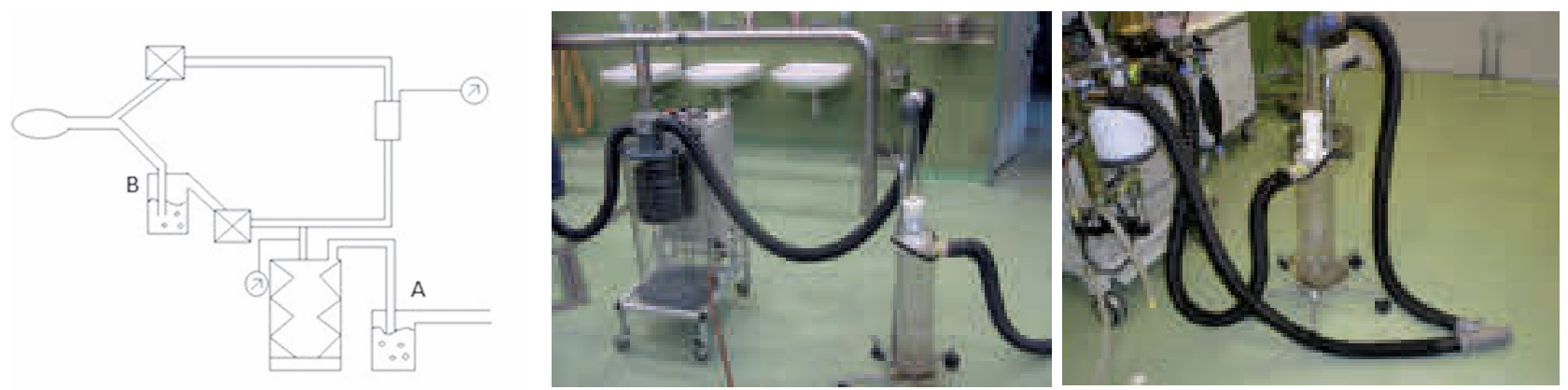

Fig. 1a Graphic scheme and pictures showing the two different locations for the underwater seal in the breathing circuit. A: ventilatory exhaust port and B: expiratory limb. With position B in-circuit manometers do not detect PEEP.
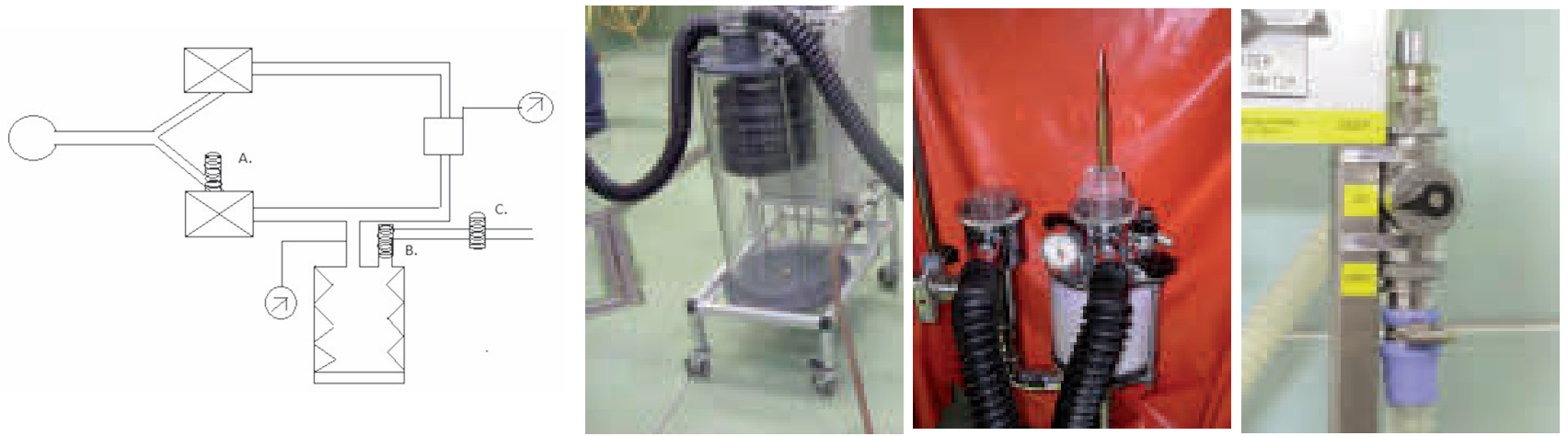

Fig. 1b Graphic scheme and pictures showing the two different locations to modify a valve into a spring loaded valve. A: the expiratory valve of the circle system, and B: the ventilator exhaust port valve. With A. in-circuit manometers do not detect PEEP. C: A commercial spring loaded threshold resistor can be mounted at the ventilator exhaust port.

flow-resistance characteristics, possibly resulting in increased PEEP levels when expiratory flow is increased (Kacmarek et al. 1982). However, if the diameter of such a threshold valve is large enough the latter problem will not occur.

\section{The spring-loaded valve}

The spring-loaded valve is another non-gravity dependent threshold valve device that has been used during equine mechanical ventilation. The commercially available device consists of a spring that can be compressed below its equilibrium (no-load-limit) by use of a threaded knob. The force created by the compressed spring is applied over the surface area of a disc seated over the outlet orifice. Threshold pressures can be selected and maintained by the recoil properties of the spring and pressures must exceed the threshold pressu-

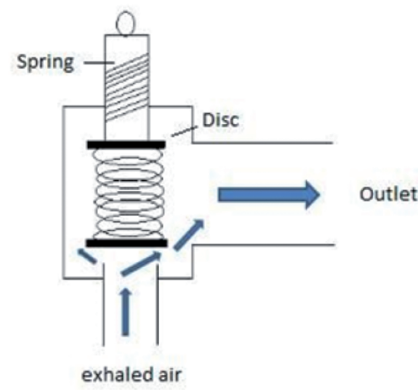

Fig. 2a Schematic presentation of a comercially available treshold resistor, which can be mounted e.g. onto the ventilator exhaust port. Hereby the amount of PEEP can be regulated by the force of the adjustable spring on the disk. Once the force of the spring is overcome by the exhaled air, the disk opens and the exhaled air can escape. re to allow gas relief through the device. Again, increases in expiratory flow rates can result in alterations of PEEP levels (Kacmarek et al. 1982) if the orifice of such a device is too small. This principle has been applied by several workers, e.g. Schürmann et al. (2005) and Hopster et al. (2007) who mounted the spring loaded valve at the exhaust port of the bag-in-the-box ventilator. Alternatively the expiratory valve of a circle system can be modified by mounting an adjustable spring on the valve dome that is in contact with the expiratory valve disc, thereby creating a spring loaded expiratory valve. (Figure 2; Schramel, personal communication).

\section{The magnetic valve}

The magnetic valve also belongs to the non-gravity dependent PEEP devices and has been used in equine anaesthesia by Wilson et al (1991) attached to the pressure relief valve of

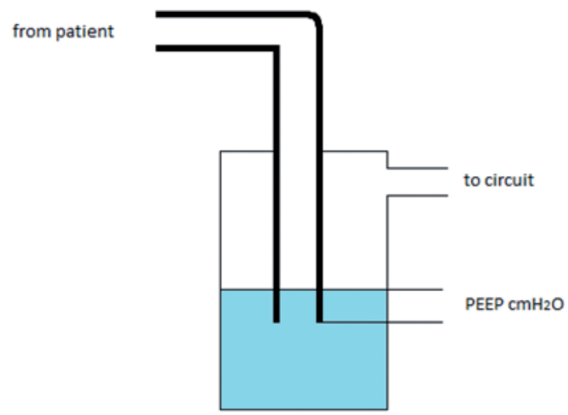

Fig. $2 b$ Schematic presentation of an underwater seal threshold resistor. The depth to which the expiratory hose is submerged within the water reservoir determines the amount of PEEP achieved. 
the ventilator. The valve uses the magnetic attraction between a bar magnet and a metallic disc on the outlet orifice and was first described by Hobelmann et al. in 1977. The force of the magnetic attraction is inversely related to the distance between disc and magnet. Hence, threshold pressures can be adjusted by changing the distance between magnet and metallic disc by turning a threaded knob. The principle is thus very similar to the spring-loaded valve and again high expiratory flow can result in increased PEEP levels if the diameter of the valve is too small; care must be taken to ensure that the opening pressure of the magnetic valve does not exceed the set PEEP level (Kacmarek et al. 1982).

\section{Orificial resistors}

Differently to threshold valves are orificial resistors, which are simple devices that establish a fixed resistance at the expiratory limb by increasing the resistance to flow as a result of their radius. The magnitude of the generated pressure is directly related to the resistance and the flowrate of gas. It is important to mention that in this case PEEP is diminishing over time and therefore dependent on expiratory time. The functioning is like exhaling through narrowed lips done by asthma patients. Three devices, which are commonly used in small animal medicine, are the endotracheal tube adapter, the screw clamp and the variable orifice plate. PEEP levels are linearly affected by increasing expiratory flow rates resulting in higher PEEP levels. Therefore they are not considered safe in equine patients who are capable of creating large and not constant expiratory flows (Kacmarek et al. 1982). To the author's knowledge there are no published studies using these devices in equine anaesthesia and they will not be further discussed within this review.

\section{Time lag with different PEEP devices}

The time it takes to reach a selected PEEP level varies for different add-on PEEP devices. The time lag is considered to be independent of the fresh gas flow. The onset of PEEP when using an underwater seal was demonstrated to be significantly faster compared to a spring loaded PEEP valve, a finding attributed to the higher resistance of the valve compared to the underwater seal (Beckham and Boyer 1976). The time factor is important for clinical situations that demand frequent adjustment of PEEP levels (e.g. stepwise recruitment manoeuvre).

During an in vitro trial using a large animal circle system and two different types of PEEP devices (underwater seal and spring loaded device in the expiratory limb) the faster onset of PEEP with the underwater seal was confirmed. Unexpectedly, time to reach PEEP was slower with a fresh gas flow of $5 \mathrm{~L} / \mathrm{min}$ versus $10 \mathrm{~L} / \mathrm{min}$ (Kü/s, personal unpublished observations). Using both devices in anaesthetized horses the faster performance of the underwater seal remained, however, times to reach PEEP were in general much longer (16.4 seconds for the underwater seal and 27.4 seconds for the spring-loaded valve) in vivo compared to the in vitro setting $(1.1$ seconds for the underwater seal and 1.75 seconds for the spring-loaded valve). Also, in vivo no relevant differences in the time to reach PEEP were observed using different fresh gas flows (Hopster, personal unpublished observations). These observations may be due to influences of lung volume and respiratory dynamics. The application of PEEP in vivo occurred during intermittent positive pressure ventila- tion; in contrast, in vitro an artificial, rigid lung received PEEP. To the authors knowledge no detailed studies exist investigating the different components of the circle and patient system on the impact of PEEP. It remains to each individual user to carefully observe the time it takes to build up PEEP as well as potential changes using different fresh gas flow rates. Thus, it is paramount to monitor the pressures within the circuit.

\section{Monitoring of PEEP}

When PEEP valves are added to anaesthetic machines it is important to note that both the location of the threshold valve and of the airway pressure measurement device in the circuit will determine if the applied PEEP is being detected within the circle system. Typically airway pressure manometers are mounted in the circle system or at the level of the bag- in- thebox ventilator but airway pressures can also be measured at the $Y$-piece of the breathing circuit via a dedicated spirometer sensor (Moens 2010).

In an experimental in-vitro setting similar PEEP was detected at all locations within the circle system when the PEEP device was applied to the exhaust port of the ventilator. In contrast no PEEP was detectable via in- circuit pressure measurement when an underwater seal was mounted in the expiratory limb or a spring loaded expiratory valve was used. The presence of PEEP could only be confirmed by measurement with the spirometer sensor placed between the Y-piece of the breathing circuit and the endotracheal tube (Kü/s, personal unpublished observations).

In conclusion, conventional large animal anaesthetic systems and ventilators can be modified to provide sufficient PEEP by adding threshold valve devices. Close monitoring of the PEEP applied is of great importance. Both, the exact position of the PEEP device and its measurement device in the system must be considered for accurate and safe application of PEEP.

\section{Manufacturer addresses}

1 Vetronic Services LTD, 12 Henley's Business Park, Manor Road, Abbotskerswell, Devon TQ12 5NF, UK

2 University of Veterinary medicine, Austria and CSEM, Switzerland

\section{Conflict of interest statement}

The author's state no conflict of interest.

\section{References}

Beadle R. E., Robinson N. E., Sorenson P. R. (1975) Cardiopulmonary effects of positive end-expiratory pressure in anesthetized horses. Am. J. Vet. Res. 36, 1435-1438

Beckham R. W., Boyer F. E. (1976) Comparison of three types of PEEP devices. Respir. Ther. 6, 55-56, 58

Bringewatt T., Hopster K., Kästner S. B., Rohn K., Ohnesorge B. (2010) Influence of modified open lung concept ventilation on the cardiovascular and pulmonary function of horses during total intravenous anaesthesia. Vet. Rec. 25, 1002-1006

Christensen E. F., Jensen R. H., Schønemann N. K., Petersen K. D. (1995) Flow-dependent properties of positive expiratory pressure devices. Monaldi Arch. Chest Dis. 50,150-153

Hall L. W., Gillespie J. R., Tyler W. S. (1968) Alveolar-arterial oxygen tension differences in anaesthetized horses. Br. J. Anaesth. 40, 560 
Hall L. W., Trim C. M. (1975) Positive end-expiratory pressure in anaesthetized spontaneously breathing horses. Br. J. Anaesth. 47, 819-824

Hobelmann C. F. jr, Smith D. E., Virgilio R. W. (1977) A Magnetic PEEP Valve. Anesth. Analg. 56, 580-582

Hopster K. (2007) Influence of ventilation using the 'open-lung-concept $^{\prime}$ during anaesthesia of horses on the intra- and postoperative pulmonary function. Diss. Med. Vet. Hannover

Hopster K., Kästner S. B., Rohn K., Ohnesorge B. (201 1), Intermittent positive pressure ventilation with constant positive end-expiratory pressure and alveolar recruitment manoeuvre during inhalation anaesthesia in horses undergoing surgery for colic, and its influence on the early recovery period. Vet. Anaesth. Analg. 38, 169-177

Hopster K., Wogatzki A., Conze P., Kästner S. B. (2016a) Effects of positive end-expiratory pressure titration on intestinal oxygenation and perfusion in isoflurane anaesthetised horses. Equine Vet. J. doi: 10.1111 /evj.12555 (epub ahead of print)

Hopster K., Rohn K., Ohnesorge B., Kästner S. B. (2016b). Controlled mechanical ventilation with constant positive end-expiratory pressure and alveolar recruitment manoeuvres during anaesthesia in laterally or dorsally recumbent horses. Vet. Anaesth. Analg. doi: 10.1111/vaa.12390 (epub ahead of print)

Iff I., Levionnois O., Moens Y. (2007) Alveolar recruitment manoeuvre in a Shetland pony anaesthetized for laparoscopic castration. Wien. Tierärztl. Mschr. 94, 264-268

Kacmarek R.M., Dimas S., Reynolds J., Shapiro B. A.(1982) Technical aspects of positive end-expiratory pressure (PEEP): Part I. Physics of PEEP devices. Respir. Care. 27, 1478-1489

Levionnois O., Iff I., Moens Y. (2006).Successful treatment of hypoxemia by an alveolar recruitment maneuver in a horse during general anaesthesia for colic surgery. Pferdeheilkunde 22, 333-336

McDonell W. N., Hall L. W. (1979) Radiographic Evidence of Impaired Pulmonary Function in Laterally Recumbent Anaesthetised Horses. Equine Vet. J. 11, 24-32

Moens Y. P. S. (2010) Clinical application of continuous spirometry with a pitot-based flow meter during equine anaesthesia. Equine Vet. Educ. 22, 354-360

Schürmann P., Hopster K., Rohn K., Ohnesorge B. (2008) Optimized gas exchange during inhalant anaesthesia in horses using "open lung concept" ventilation. Pferdeheilkunde 24, 236-242

Wettstein D., Moens Y., Jaeggin-Schmucker N., Böhm S. H., Rothen H. U., Mosing M., Kästner S. B., Schatzmann U. (2006) Effects of an alveolar recruitment maneuver on cardiovascular and respiratory parameters during total intravenous anesthesia in ponies. Am. J. Vet. Res. 67, 152-159

Wilson D. V., McFeely A. M. (1991) Positive end-expiratory pressure during colic surgery in horses: 74 cases (1986-1988). J. Am. Vet. Med. Assoc. 199, 917-921

Erweiterte Zusammenfassung

\section{Der Einsatz von Widerstandsventilen zum Aufbau von positivem end-exspiratorischen Druck (PEEP) in Groß- tierventilatoren und -atemsystemen}

Der Gebrauch von positiv-endexpiratorischem Druck (PEEP, aus dem Englischen "positive end-expiratory pressure") und alveolären Rekrutierungsmanövern (ARM) ist eine vielversprechende Behandlungsoption für intraoperativen Lungenkollaps und konsekutiver Hypoxämie beim Pferd. Die dazu beim Pferd benötigten PEEP Drücke sind mit bis zu $30 \mathrm{~cm} \mathrm{H}_{2} \mathrm{O}$ deutlich höher als in der Human- oder Kleintiermedizin. Bedauerlicherweise sind nur die nevesten, motorengesteverten Großtierventilatoren, die nicht das 'bag in the box' Prinzip nutzen, dazu befähigt automatisch ausreichend hohe PEEP Stufen für Pferde zu erreichen. Um dennoch eine große Bandbreite an PEEP Stufen in den herkömmlichen 'bag in the box' Großtierventilatoren und -kreissystemen zu erzeugen, können Grenzventile eingesetzł werden. Diese Grenzventile sind von Widerstandsdurchlässen deutlich zu unterscheiden. Widerstands- durchlässe sind simple Geräte, die einen fixen Widerstand im Ausatemschenkel des Kreissystems aufgrund ihres Durchmessers bilden. Das Ausmaß des so erzeugten Druckes ist dabei direkt proportional zum Widerstand und der Gasflußrate. Dies bedeutet, dass PEEP über die Zeit abnimmt und somit von der Ausatemzeit abhängt. Erhöhter Ausatemfluss resultiert in größerem PEEP. Aufgrund der hohen Varianz des Atemflusses beim Pferd können diese Geräte in dieser Spezies daher nicht empfohlen werden.

Externe PEEP Grenzventile hingegen bilden durch verschiedene Mechanismen eine konstante, vorhersehbare und quantifizierbare Kraft gegen den Ausatemdruck und setzen dadurch einen konstanten Schwellendruck. Nur Ausatemdrücke, die diese Kraft überwinden, können den PEEP Apparat passieren. Die Höhe des dadurch entstehenden positiv end-exspiratorischen Druckes ist abhängig von dem gesetzten Schwellenwert.

Die Unterwasserfalle, das Federventil und das magnetische Ventil sind sowohl im Ausatemschenkel des Kreissystems als auch an der Gasabsaugung des 'bag in the box' Ventilators möglich. Beim Unterwasserventil wird in diesem Falle z.B. eine Röhre, die mit dem Ausatemschenkel des Kreissystemes verbunden ist, in ein mit Wasser gefülltes Gefäß verbracht, wobei die Höhe der Wassersäule dem aufgebauten Druck entspricht. Sobald der Druck im Ausatemschenkel des Kreissystems den so aufgebauten Schwellendruck überschreitet, wird Wasser aus der eingetauchten Röhre verdrängt und erlaubt somit dem Gas durch das Wasser zu strömen und über den Ausatemschenkel des Kreissystems auszutreten.

Von den in der Pferdeanästhesie beschriebenen PEEP-Ventilen wurde die Wasserfalle als das Ventil mit fast idealen Widerstandeigenschaften und der größten Übereinstimmung zwischen den eingestellten und tatsächlich erreichten Drücken beschrieben. Nachteilig ist insbesondere die Sperrigkeit des Systems. Wie auch bei dem Feder- und Magnetventil ist der Qualität der Beziehung zwischen Fluss und Widerstand besondere Aufmerksamkeit zu schenken, da es bei zu kleinem Durchmesser des Ventiles bei erhöhtem Ausatemfluss zu ungeplant hohem PEEP kommen kann. Die Zeit, die benötigt wird, um eine stabiles PEEP-Stufe im System zu etablieren, ist abhängig von dem jeweiligen Grenzventil und kann ebenso von etlichen anderen Faktoren beeinflusst werden, wie z.B. der Gesamtgasmenge im Kreissystem, der Art des Ventilators oder der individuellen Pferdelunge. Auch ist die Position des PEEP-Ventils und des Manometer von Bedeutung, um in der Lage zu sein, entstandenen PEEP im System messen und somit überwachen zu können. Wird beispielsweise eine Wasserfalle in den Exspirationsschlauch zwischengeschaltet, kann PEEP nur am Y-Stück gemessen werden. In einer Studie mit einer künstlichen Lunge war die Zeit bis zum Erreichen eines stabilen PEEP im System kürzer wenn höhere Frischgasflüsse verwendet wurden. Am lebenden Tier hingegen war die Zeit bis zum Erreichen eines stabilen PEEP unabhängig vom Frischgasfluss aber signifikant langsamer als in der Kunstlunge. Es ist daher unabdingbar, die Drücke im Kreisatemsystem zu überwachen und für jedes Pferd individuell die Zeit zu bestimmen, die benötigt wird, um einen stabilen PEEP zu erreichen.

Schlüsselwörter: Anästhesie, Ventilation, Positiv End-Expiratory Pressure, PEEP, Alveolar Recruitment Manoeuvre, ARM, Ventilator, Widerstandsventil, Pferd 